\title{
SISTEM INFORMASI GEOGRAFIS RANCANGAN PETA DIGITAL RUTE ANGKUTAN UMUM KOTA BANDAR LAMPUNG
}

\author{
Dwi Marisa Efendi \\ Dosen Teknik Komputer, STMIK Dian Cipta Cendikia Kotabumi \\ E- Mail : Dwimarisa89@gmail.com
}

\begin{abstract}
ABSTRAK
Saat ini perkembangan teknologi informasi sangat berkembang dengan pesat bahkan tidak terbendung lagi. Baik masalah komunikasi, yang belakangan ini seakan tidak ada jarak lagi, segala sesuatu terasa dekat, itu semua karena teknologi. Seiring dengan perkembangan ilmu dan teknologi, muncul suatu perkembangan teknologi yaitu GPS (Global Positioning System). Bertujuan untuk mengetahui letak tempat yang akan dituju dan mengetahui dimana pengguna berada dengan bantuan sinyal satelit, GPS sendiri dapat memberikan informasi yang tepat dan akurat mengenai posisi, kecepatan, arah dan waktu (Lukmana, 2014).

Dalam penelitian ini, peneliti merancang dan membangun aplikasi Rancangan peta digital rute angkutan umum di Kota Bandar Lampung berbasis web dengan yang memanfaatkan teknologi GIS di dalamnya. Aplikasi berguna untuk pencarian rute angkutan kota (Angkot) dan Bus Rapid Transit (BRT) di Kota Bandar Lampung, sehingga pengguna tidak lagi merasa kesulitan dalam mencari angkutan umum untuk menuju lokasi tujuan mereka terutama bagi para pendatang di Kota Bandar Lampung.
\end{abstract}

Selain itu aplikasi ini dapat menampilkan informasi mengenai trayek angkot dan BRT sehingga dapat menambah wawasan pengguna. Dalam membangun aplikasi peneliti menggunakan metode Xtreme Programing dan menggunakan Macromedia dreamweaver 8. Hasilnya aplikasi "Sistem Infromasi Geografis Pencarian Rute Angkutan Umum Kota Bandar Lampung” berhasil dibangun dan berguna bagi setiap pengguna yang telah menggunakan aplikasi ini,

Kata Kunci : GIS, Angkutan Umum, Angkot, BRT, Rute, Bandar Lampung.

\section{ABSTRACT}

Currently the development of information technology is growing rapidly no longer unstoppable again. Good communication problem, this very no distance anymore, everything feels close, it's all because of technology. Along with the development of science and technology, emerged a technological development of GPS (Global Positioning System). Aiming to know where the place will go and remember where users are with the help of satellite signals, GPS itself can provide accurate and precise information about position, speed, direction and time (Lukmana, 2014).

In this study, researchers designed and built the application of digital map design of public transportation routes in Bandar Lampung City web-based with the use of GIS technology in it. The application is useful for searching the route of urban transport (Angkot) and Bus Rapid Transit (BRT) in Bandar Lampung City, so that users no longer find it difficult to find public transportation to reach their destination, especially for migrants in Bandar Lampung City.

In addition, this application can display information about angkot and BRT routes so it can add insight users. In building the application of the researcher using Xtreme Programing method and using Macromedia Dreamweaver 8. The result of the application "Geographic Information System of Public Transport Route Search Bandar Lampung City" successfully built and useful for every user who has used this application,

Keywords: GIS, Public Transport, Angkot, BRT, Route, Bandar Lampung. 


\section{PENDAHULUAN \\ 1.1 LatarBelakang}

Saat ini perkembangan teknologi informasi sangat berkembang dengan pesat bahkan tidak terbendung lagi.Baik masalah komunikasi, yang belakangan ini seakan tidak ada jarak lagi, segala sesuatu terasa dekat, itu semua karena teknologi.Di Indonesia perkembangan teknologi semakin terasa manfaatnya tidak hanya dalam komunikasi saja, dalam hal informasi suatu tempat pemanfaatan informasi berpengaruh.Salah satu teknologi yang sedang banyak digunakan adalah smartphone yang dilengkapi dengan koneksi internet.Dalam perkembangannya smartphone kini hadir dengan berbagai macam merek, dan spesifikasi serta harga yang semakin ramah bagi kantong masyarakat Indonesia yang kebanyakan memiliki perekonomian menengah ke bawah.Dengan demikian smartphone saat ini tidak lagi menjadi barang yang mewah, sehingga kebutuhan dan pemanfaatan smartphone semakin tinggi. Seiring dengan perkembangan ilmu dan teknologi, muncul suatu perkembangan teknologi yaitu GPS ( Global Positioning System). Bertujuan untuk mengetahui letak tempat yang akan dituju dan mengetahui dimana pengguna berada dengan bantuan sinyal satelit, GPS sendiri dapat memberikan informasi yang tepat dan akurat mengenai posisi, kecepatan, arah dan waktu (Lukmana, 2014).

GPS inisen diri sudah tertanam pada smartphone canggih dengan system operasi Android, dengan demikian setiap pengguna dapat mengetahui dimana posisi pengguna tanpa takut tersesat disuatut empat yang tidak diketahuinya. Kota Bandar Lampung merupakan salah satu kota besar yang ada di Indonesia dengan populasi yang begitu padat yaitu sekitar satu juta jiwa( Badan Pusat Statistik Provinsi Lampung, 2014).

Selain dengan banyaknya pendatang terutama banyaknya mahasiswa yang merantauke Bandar Lampung untuk melanjutkan pendidikannya, Kota Bandar Lampung juga merupakan kota transit bagi para masyarakat yang akan menyebrang dari pulau Sumatera menuju pulau Jawa ataupun sebaliknya. Terkadang masyarakat khususnya pendatang baru mengalami beberapa permasalahan seperti kurangnya pengetahuan akan informasi mengenai alat transportasi umum khususnya angkutan kota dan bus rapid transit (BRT) Bandar Lampung apa yang akan digunakan untuk mencapai tujuan mereka, nama jalan, rute trayek angkutan kota sehingga membuat aktifitas terganggu. Rancangan Peta Digital Rute Angkutan Umum Kota Bandar Lampun ini penulis lakukan guna mencapai tujuan yang di inginkan oleh calon penumpang angkutan kota ataupun angkotan umum lainnya.

\subsection{Identifikasi Masalah}

Berdasarkan latar belakang yang telah diuraikan di atas, dapat diketahui identifikasi masalah sebagai berikut:

1. Kota Bandar Lampung merupakan kota transit penumpang dari Sumatra maupun jawa sehingga perlunya informasi lokasi angkutan umum yang ada di Bandar Lampung guna mencapai tujuan mereka.

2. Kurangnyapengetahuanakaninformasim engenaialattransportasiumumkhususnya angkutankotadan bus rapid transit (BRT) Bandar Lampung.

3. Mengantisipasi kelonjakan harga tarif baru angkutan umum dan bus rapid transit (BRT) karena kurangnya informasi.

\subsection{BatasanMasalah}

Rancangan peta digital rute angkutan umum di kota Bandar Lampung ini memiliki batasan sebagai berikut.

1. Rancangan peta digital inihany amenampilkan informasi trayek angkutan kotadan bus rapid transit (BRT) Bandar Lampung yangberada di kota Bandar Lampung.

2. Aplikasi ini hanya menampilkan hasil pencarianruteangkutankotadan bus rapid transit (BRT) Bandar Lampung yang berada di kota Bandar Lampung.

3. Penerapan peta digital pencarian rute angkutan umum di Bandar Lampung berbasis web ini menggunakan metode Extreme Programming. 
4. Data trayekangkutankotadan bus rapid transit (BRT) Bandar Lampung di kota Bandar Lampung berdasarkan data yang diperolehdariDinasPerhubungan Kota Bandar Lampung

5. Aplikasi ini berbasis web, sehingga hanya dapat dijalankan pada perangkat (handphone) atau laptop memiliki akses jaringan internet.

6. Aplikasi ini membutuhkan koneksi internet dana akses GPS.

\subsection{TujuanPenelitian}

Tujuan Penelitian ini bertujuan untuk merancang dan membangun aplikasi Sistem Informasi Geografis peta digital rute angkutan umum di kota Bandar Lampung sebagai petunjuk untuk mengakses informasi yang berkaitan dengan rute angkutan umum di kota Bandar Lampung

\subsection{Manfaat Penelitian}

Manfaat yang diperoleh dari penelitian adalah diharapkan masyaraka tkota Bandar Lampung atapun pendatang sebagai pengguna angkutan umum dapat terbantu dalam hal menemukan rute angkutan kota dan bus rapid transit (BRT) Bandar Lampung di kota Bandar Lampung.

\section{METODE PENELITIAN}

Metodologi yang akan digunakan dalam penelitian ini adalah Xtreme Programming (XP) yang merupakan salah satu metode yang tergolong ke dalam Agile Methodology. Terdapat lima tahapan utama yang akan dilalui dalam pengembangan sistem.

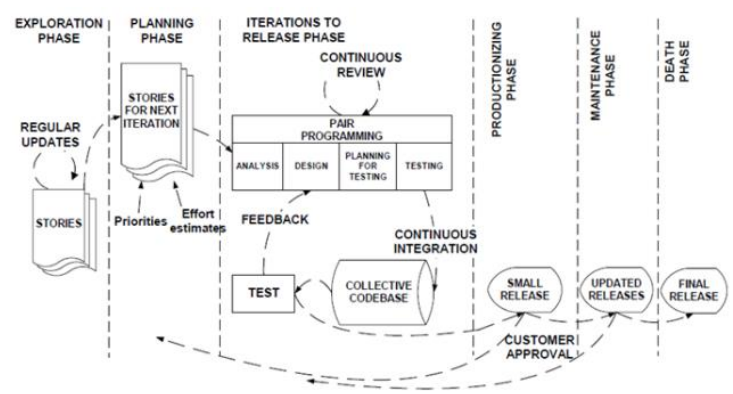

Gambar 1 Tahap Pengembangan Sistem

Tahapan utama dalam pengembangan sistem informasi dengan menggunakan Xtreme Programming (XP) yaitu :
Explorasi, Planning,iterasi pengembangan sistem (analisis, desain, testing), produksi, maintenance, dan mengakhiri proyek dengan mengeluarkan final relase. Akhir disetiap fase yang dikembangkan merupakan milestoneatas fase tersebut sebelum bergerak ke fase berikutnya.

\subsection{Populasi}

Yang menjadi populasi pada penelelitian ini adalah seluruh angkutan kota dan Bus Rapid Transityang beroperasi di Kota Bandar Lampung yang meliputi 11 rute jalur angkutan kota dan 3 jalur Bus Rapid Transit.

\subsection{Sampel}

Penelitian ini populasinya hotrogen (angkutan kota dan Bus Rapid Transit), rute angkutan beberapa di tunjukan secara langsung dan sebagian lagi mengambil beberapa literatur yang ada.

\section{HASIL DAN PEMBAHASAN}

\subsection{Alur Sistem Berjalan}

Analisa merupakan suatu kegiatan yang bertujuan untuk mempelajari serta mengevaluasi suatu bentuk permasalahan yang ada pada sebuah sistem. Dalam analisa sistem akan ditemukan masalah yang mungkin akan mempengaruhi kerja sistem. Agar sistem yang dirancang dapat berjalan sebagaimana mestinya, perlu dilakukan analisis terhadap kinerja sistem yang pada akhirnya bertujuan untuk pengembangan sistem.

Dari pengamatan yang penulis lakukan dapat dilihat bahwa informasi keberadaan rute angkutan umum di kota Bandar Lampung bagi mahasiswa yang baru memulai kuliah masih sulit dalam mencari informasinya yaitu dengan mencari melalui google, bertanya langsung dengan orang lain untuk mengetahui rute angkutan / jalur yang dilewatinya dan angkutan yang dipilihnya. Kemudian setelah naik angkutan umum tidak mengetahui biaya/tarif yang di sepakati, karena terkadang masih banyak kejanggalan atau tidak sesuainya tarif angkutan karena kurangnya informasi. 


\subsection{Kelemahan Sistem Berjalan}

Setelah dilakukan analisa terhadap sistem yang sedang berjalan, ditemukan beberapa kelemahan. Adapun kelemahan pada sistem yang sedang berajalan adalah :

1. Membutuhkan waktu yang lama dalam pencarian informasi

2. Informasi yang diperoleh kurang akurat.

\subsection{Iterasi Peluncuran Perangkat Lunak}

Metode pengembangan dalam iterasi ini sistem yang dipilih dalam penelitian adalah UnifiedProcess (UP).Tahap-tahap yang dilakukan dalam pengembangan sistem aplikasiini adalah.

\section{1) Inception}

Pada tahap ini dilakukan pengumpulan data yang berupa data spasial rute trayek angkutan kota dan bus rapid transit (BRT) Bandar Lampung di kota Bandar Lampung. Data spasial ini diperoleh langsung dilapangan dengan menggunakan media perangkat handphone atau laptop yang mengakses aplikasi "Map Server" untuk mendapatkan koordinat rute masing-masing trayek angkutan umum. Data spasial terdiri dari koordinat koordinat rute trayek angkutan umum yang telah digambarkan kedalam maps. Adapun rute trayek angkutan umum di Bandar Lampung sebagai berikut.

1. Trayek angkutan kota di kota Bandar Lampung
a. Tanjung Karang - Rajabasa
b. Tanjung Karang - Sukaraja
c. Sukaraja - Panjang
d. Tanjung Karang - Garuntang
e. Tanjung Karang - Way Kandis
f. Tanjung Karang - Kemiling
g. Tanjung Karang - Sam Ratulangi
h. Tanjung Karang - Sukarame
i. Tanjung Karang - Permata Biru
j. Tanjung Karang - Ir. Sutami
k. Pasar Cimeng - Lempassing
1. Sukaraja-Lempasing

2. Trayek bus rapid transit (BRT) Bandar Lampung di kota Bandar Lampung
a. Rajabasa-Panjang
b. Rajabasa - Sukaraja
c. Perum Korpri - Sukaraja

(Dinas Perhubungan Kota Bandar Lampung, Tahun 2015)Pada tahap ini juga dilakukan analisis kebutuhan dasar sistem dan analisis user requirement.

\section{2) Elaboration}

Perancangan sistem dan perancangan interface berlangsung pada tahap ini.Perancangan atau desain sistem dalam penelitian ini menggunakan UnifiedModelling Language (UML). Diagram-diagram UML yang dibuat dalampenelitian ini adalah sebagai berikut.
a. Use case diagram.
b. Activity diagram.
c. Sequence diagram.
d. Class diagram.

Perancangan interface (antarmuka) yang dirancang dalam aplikasi ini adalahsebagai berikut.
a. Layoutsplash screen.
b. Layout Menu Utama.
c. Layout menu Ganti Password
e. Layout menu Cari Rute.
f. Layout menu Log Out

\subsection{Analisis Sistem}

1. Peta Kota Bandar Lampung dengan informasi rute trayek angkutan kota diBandar Lampung seperti Tanjung Karang - Rajabasa, Tanjung Karang Sukaraja, Sukaraja - Panjang, Tanjung Karang - Garuntang, Tanjung Karang Way Kandis, Tanjung Karang Kemilin, Tanjung Karang - Sam Ratulangi, Tanjung Karang - Sukarame, Tanjung Karang - Permata Biru,Tanjung Karang - Ir. Sutami, Pasar Cimeng Lempasing, Sukaraja -Lempasing. Dan informasi rute trayek bus rapid transit (BRT) BandarLampung seperti Rajabasa - Panjang, Rajabasa - Sukaraja, Perum Korpri-Sukaraja.

2. Informasi detail mengenai trayek angkutan kota dan bus rapid transit(BRT) Bandar Lampung di kota Bandar Lampung.

3. Biaya setiap trayek angkutan kota dan bus rapid transit (BRT) Bandar Lampung di kota Bandar Lampung. 


\subsection{Analisis User Requirement}

Kebutuhan dasar aplikasi ini adalah sebagai berikut.

1. Sistem dapat menampilkan rute trayek angkutan kota dan bus rapid transit(BRT) Bandar Lampung di Bandar Lampung dengan menggunakan Web.

2. Sistem dapat memberikan step by step, estimasi jarak tempuh, gambar angkutan, dan estimasibiaya kepada user untuk menuju tujuan yang user inginkan.

3. Sistem dapat memberikan informasi mengenai masing-masing trayekangkutan kota dan bus rapid transit (BRT) Bandar Lampung di kotaBandar Lampung.

4. Sistem dapat merespon beberapa aksi yang diberikan oleh user.

\subsection{Perancangan Sistem}

Perancangan sistem adalah tahap setelah analisis dari siklus pengembangan sistem. Perancangan sistem di sini berupa penggambaran, perencanaan dan pembuatan sketsa atau pengaturan dari beberapa elemen yang terpisah ke dalam satu kesatuan yang utuh dan dapat berfungsi. Perancangan sistem menentukan bagaimana suatu sistem akan menyelesaikan apa yang harus diselesaikan. Tahap ini termasuk mengkonfigurasi dari komponen-komponen perangkat lunak dan perangkat keras dari suatu sistem sehingga setelah dilakukan instalasi akan benarbenar sesuai dengan rancangan awal sistem.

\subsection{Perancangan UML (Unified Modelling Language)}

Perancangan sistem atau desain system dilakukan dengan memodelkan permasalahan dalam bentuk diagram-diagram UML sebagai berikut.

\section{Use Case Diagram}

Use case diagram dibawah ini menjelaskan fungsionalitas dari aplikasi pencarian rute angkutan kota di Bandar Lampung. Pada aplikasi ini, pengguna dapat melakukan 5 interaksi antara lain akses menu posisi pengguna, akses menu cari rute, akses menu info rute trayek, akses menu bantuan, dan akses menu tentang aplikasi. Use case diagram aplikasi Balam Trans dapat dilihat pada Gambar 3.1

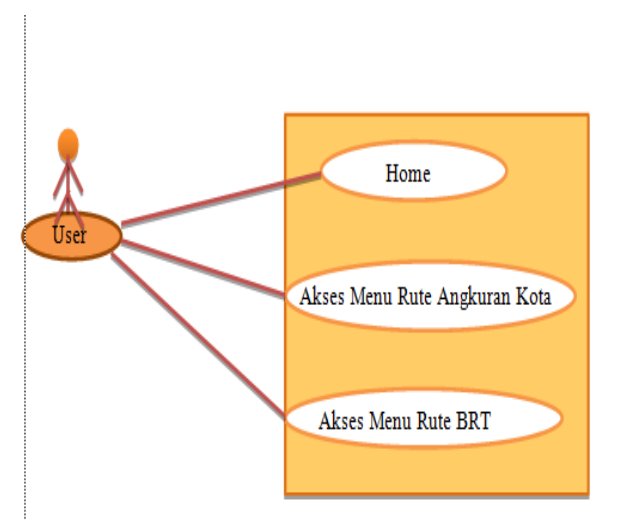

Gambar 2 Use Case Diagram User

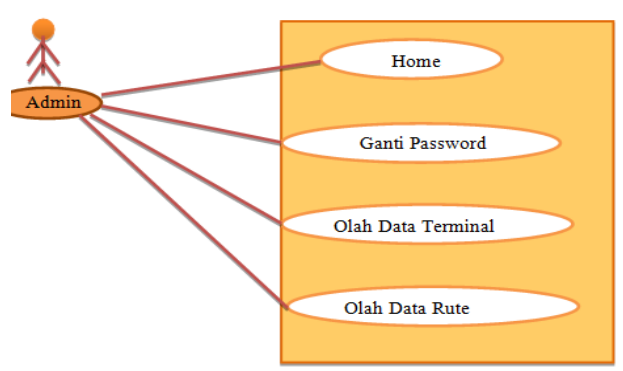

Gambar 3 Use Case Diagram Admin

2. Activity Diagram

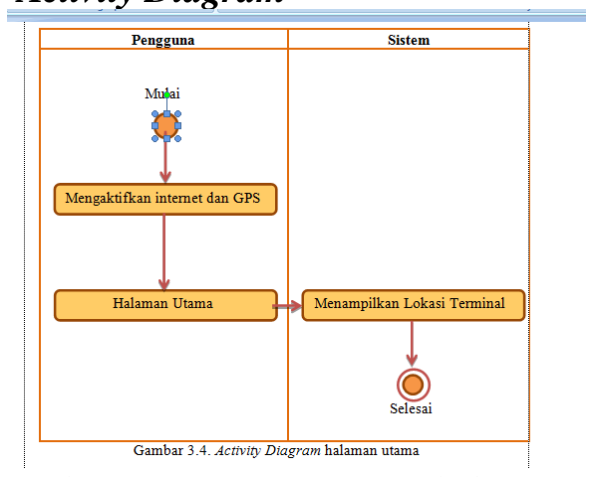

Gambar 4 Activity Diagram halaman utama 


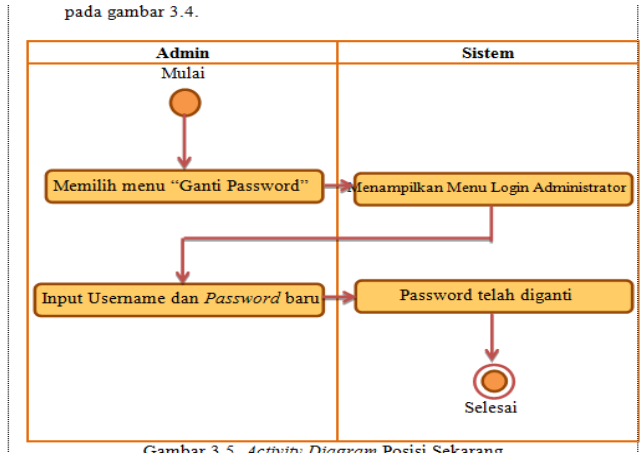

Gambar 5 Activity Diagram Posisi Sekarang

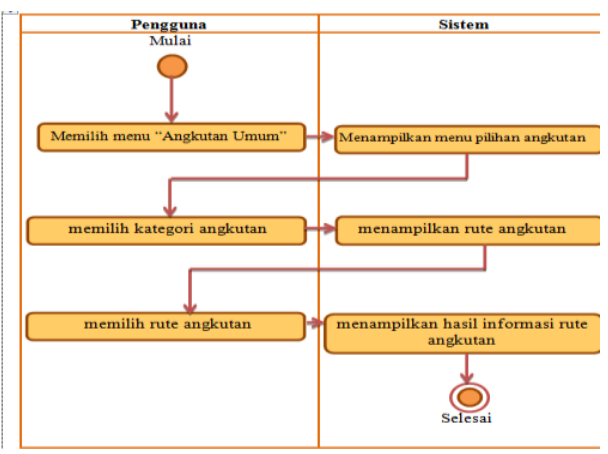

Gambar 6 Activity Diagram Angkutan umum

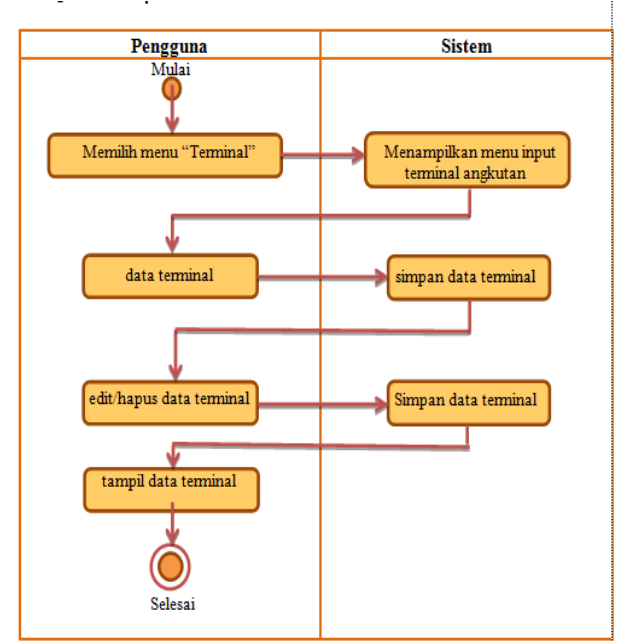

Gambar 7 Activity Diagram Admin Entry Terminal

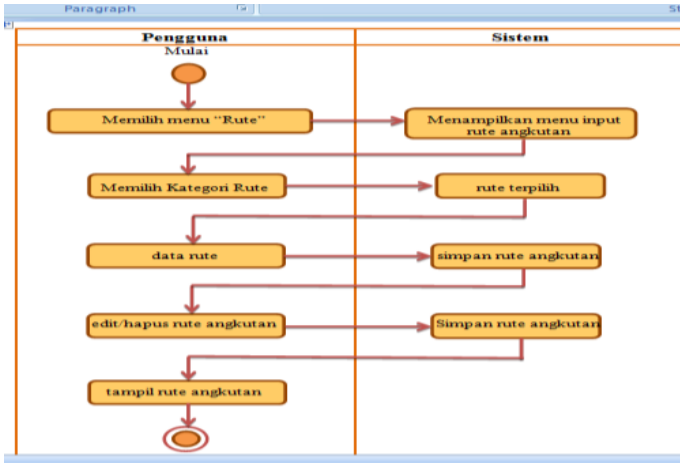

Gambar 8 Activity Diagram Admin Entry Rute

\section{Sequence Diagram}

Diagram sekuensial atau sequence diagram digunakan untuk menunjukanaliran fungsionalitas dalam use case. Pada aplikasi Balam Trans terdapat (lima) sequence diagram, yaitu sebagai berikut.

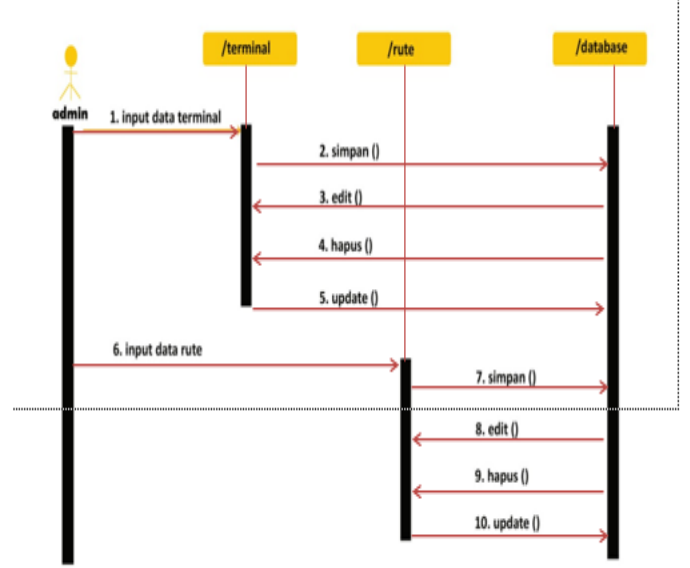

Gambar 9 Sequence diagram

\section{Class Diagram}

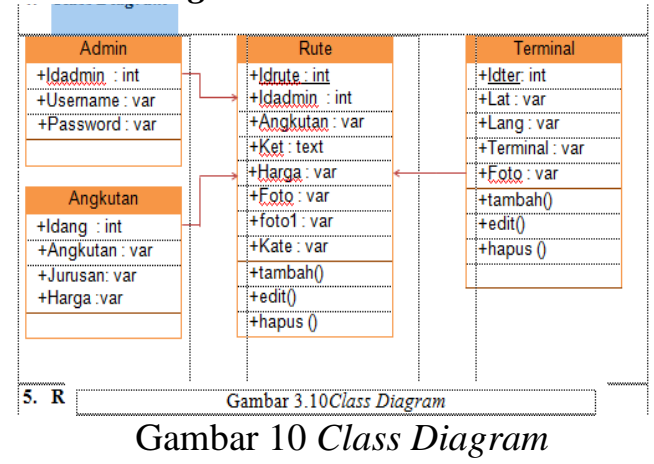




\section{Hasil Program}

Dalam implementasi system membagi halaman menjadi 2 (dua) hak akses yaitu user hanya sebagai pencari rute dan terminal sedangkan admin mempunyai hak akses untuk mengolah database

1.Halaman utamauser

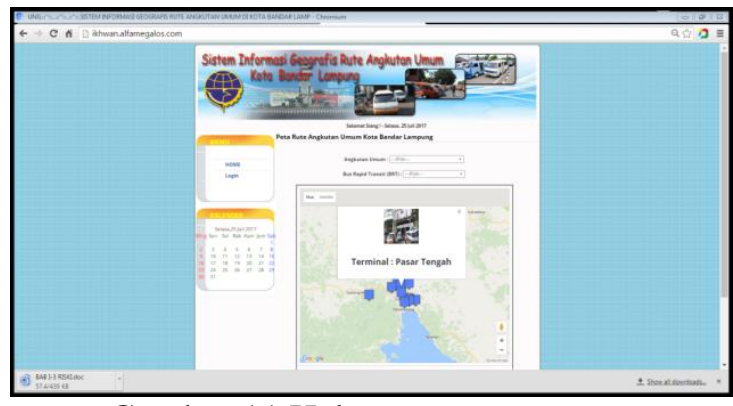

Gambar 11 Halaman utama user

2.Halaman Utama Admin

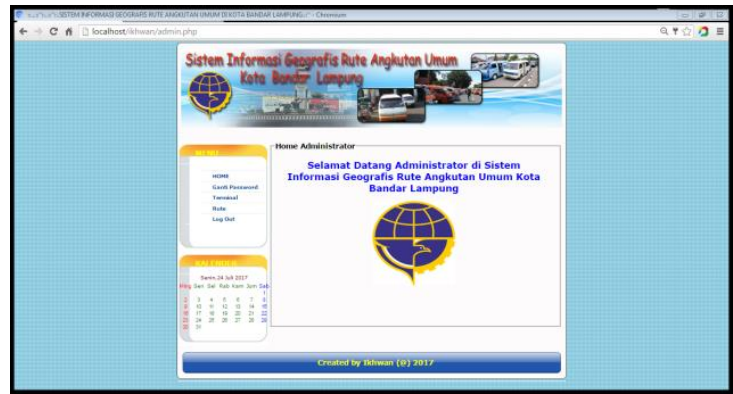

Gambar 12 Halaman utama admin

3.Halaman Ganti Password

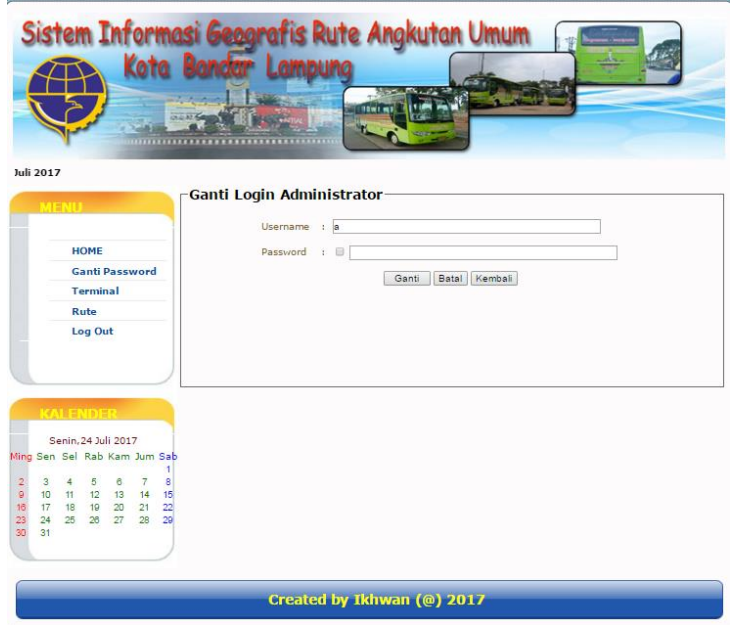

Gambar 13 Halaman ganti password

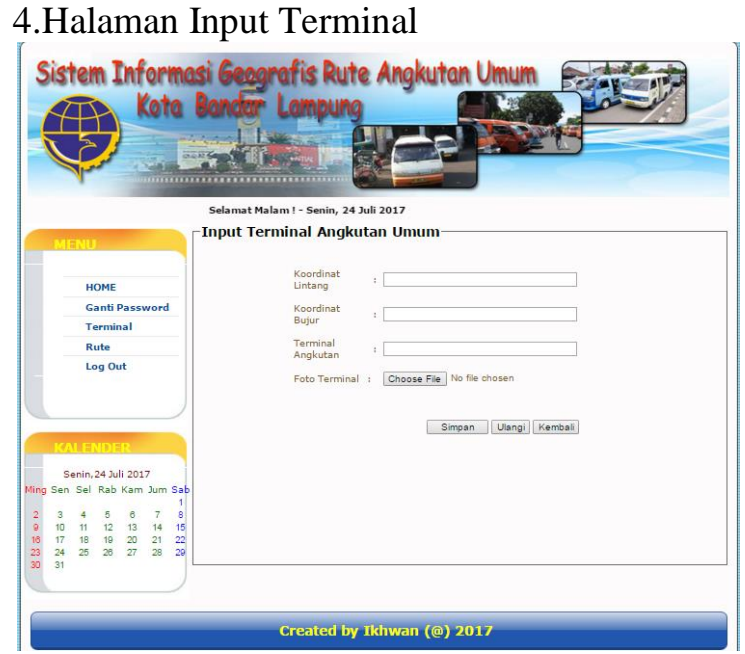

Gambar 14 Halaman Input Terminal

5.Halaman Tabel Input Terminal

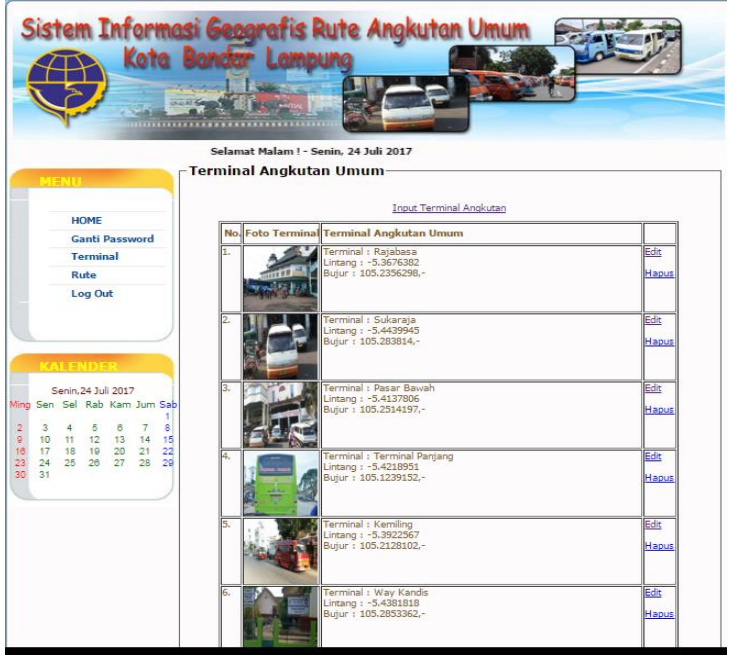

Gambar 15 Halaman Tabel Input Terminal

6.Halaman Input Rute 


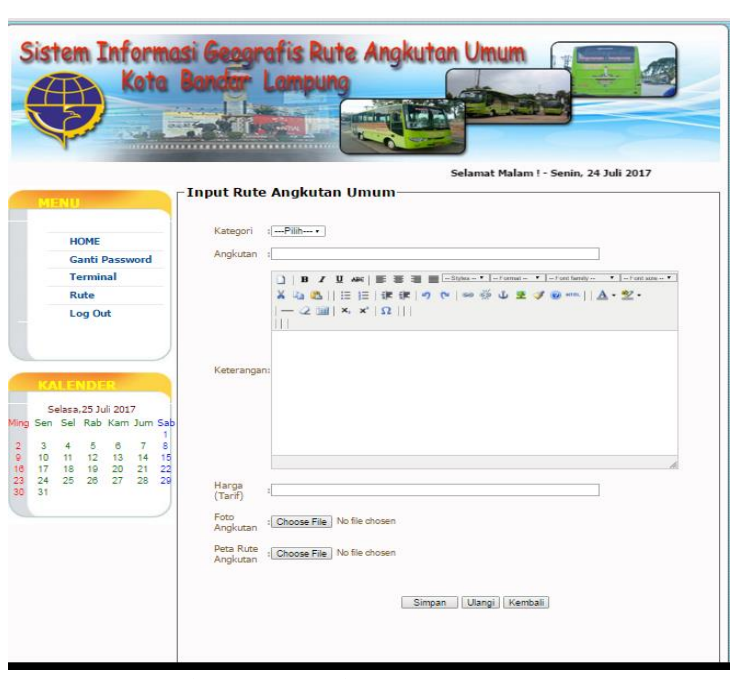

Gambar 16 Halaman Input Rute

7.Halaman Tabel Input Rute

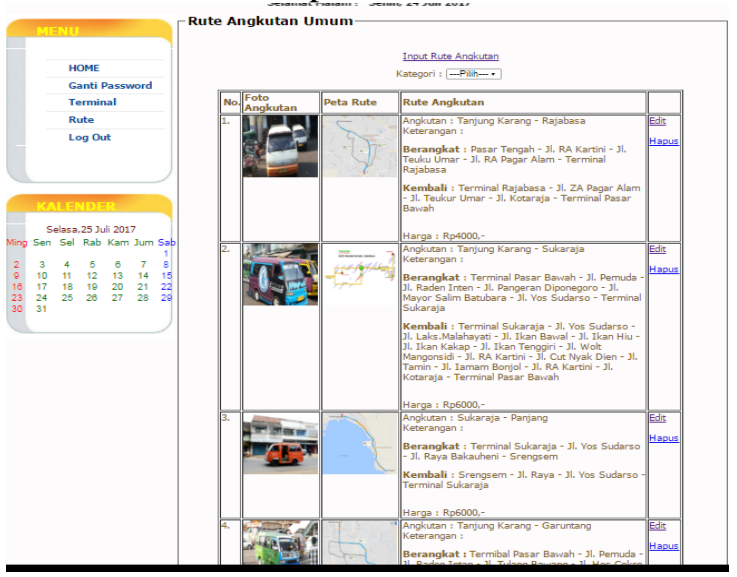

Gambar 17 Halaman Tabel Input Rute

8.Halaman Peta Rute Angkutan Umun

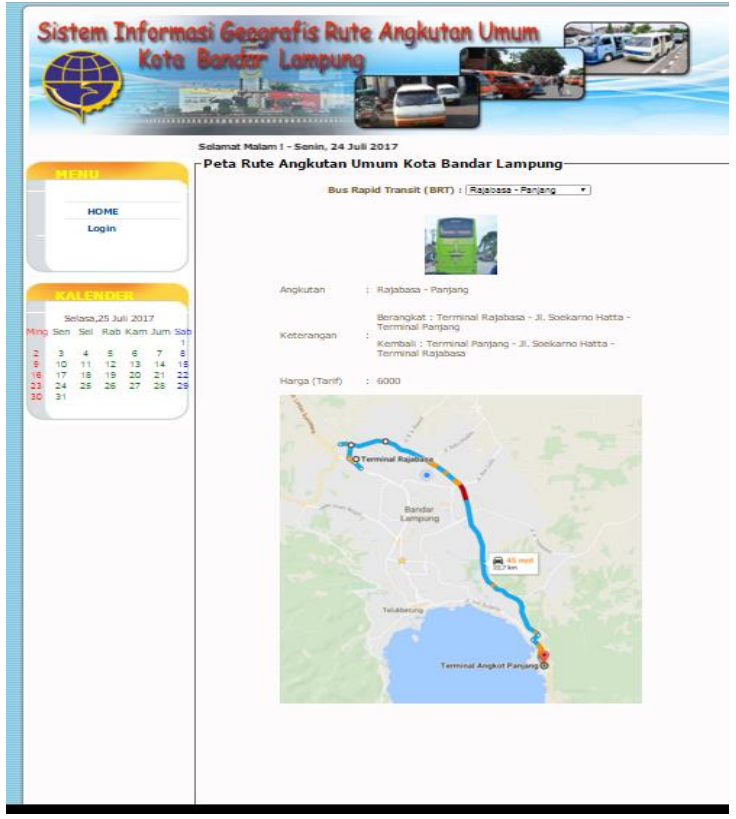

Gambar 18 Halaman Peta Rute Angkutan

\section{DAFTAR PUSTAKA}

Ariyandi Deby. 2016. Aplikasi Pencarian Rute Angkutan Umum di akses di http://docplayer.info/35347721-Aplikasipencarian-rute-angkutan-umum-di-bandarlampung-berbasis-mobile-android-skripsioleh-deby-ariyandi.html pada 19 Februari 2016

Badan Pusat Statistik Provinsi Lampung di akses di https://lampung.bps.go.id/linkTabelStatis/v iew/id/12pada 19 Februari 2016 Dinas Perhubungan Provinsi Lampung. 2016. Di akses di http://dishub.lampungprov.go.id/home\# pada 19 Februari 2016 
